Ohio, and a fragment weighing about twelve ounces, fell upon a farm near Rochester, Indiana, a part of it being secured by Prof. Kirkwood. The body is described as "peculiar in its structure; being pisolitic and remarkably friable." It is inferred that no part of the mass could have escaped out of the atmosphere. The aerolite of January 23 , or rather a portion of it, after the final explosion, reached the earth in Kentucky, and is now in the collection of Dr. J. Lawrence Smith, of Louisville. The report is stated to have resembled discharges of heavy ordnance, in such close succession, that the different discharges were barely distinguishable; height at first appearance about seventy miles.

The Transit of VenUs, 1882.-In Astron. Nach., Nos. 2I33-4, we have another calculation of the elements of this transit from M. Leverrier's Tables; it is by Dr. Deichmüller, of the Observatory at Bonn, who has followed Prof. Oppölzer's method for the necessary data for reduction of the observations which are interpolatell down to short intervals in Paris time. There are special calculations for certain principal stations.

\section{THE LAND OF HISSAR AND KOLAB}

$T \mathrm{HE}$ eastern part of the dominions of the Emir of Bokhara is the belt of land between $37^{\circ} 30^{\prime}$ and $39^{\circ}$ N.L., and $67^{\circ}$ and $71^{\circ}$ E.L., borderea on the north by the now Russian province of Samarkand and the Karategin, and on the south by Afghanistan (the Balkh, Kunduz, and the Badakshan districts). It has hitherto been all but totally unknown. M. Maïeff, after having, together with Lieut. Vishnevsky and M. F. Schwarz, thoroughly explored it in 1875, gives us a description of the land of Hissar and partly that of Kolab (Isvestia of the Russ. Geog. Soc., 1876, 4 ih fasc.), with an elaborate map, based on numerous determinations of latitudes and longitudes, surveys, and barometrical measurements of heights.

Two great rivers running east and west, the upper Zerafshan on the north, and the Pandsh, or Upper Oxus, on the south, are the natural boundaries of the country. A third river, the Shehrsebz, running in the same direction under $39^{\circ}$ N.L., borders its north-western corner, and a mass of high table-lands, the Pamir, rises to the east of the Kolab district. The whole land is filled with mountains belonging to the Tian Shan system. Two main ridges, which both run north-east to south-west, and are divided by the broad valley of the Surhan, ${ }^{x}$ form the backbones of this hilly tract. Secondary ridges, either parallel to the main ones, or spreading out of them, fill the country. But at their western extremities, the mountain ridges are farlower than we know them to be in the east. Thus, the ridge between the Shehrsebz and the Surhan, now called the Hissar Ridge, ${ }^{2}$ rising above the snow-line in its eastern parts, is far lower in the western; and its highest pass, Ak-rabat, is but 4,590 feet high, whilst other passes are as low as from 2,200 to 3,600 feet above the sea-level. The second main ridge, lying to the east of the broad Surhan valley and running between it and that of the Vaksh, seems to be higher, but yet far below the highlands of Kokand or of Eastern Turkestan. Besides, tne highlands are deepiy cut into by large and broad valleys which have in their lower parts a prevailing direction south by west, running thus to the Oxus. The northwestern slope of the Hissar ridge is drained by only one river, the Guzar-daria, an affluent of the Shehrsebz; but instead of being an insigniticant stream, as on our present maps, it appears as a mighty river fed by the perpetual snows of the Sengri-dag, and its upper shores are occupied by a numerous population. East of the'Hissar ridge we see a series of broad well-peopled valleys. First, that of the Snir-abad, from about 2,500 to 900 feet high, with the towns Derbent, Baisun, and Shir-abad. Next, Tupalik on Mr. Arrowsmith's map in the foumn. Roy. Geog. Soc., I875.
Tupalan is the name of one of the upper affuents of the Surhan.

2 Its local narnes are Bash-hurd, Baisun-tau, Meshai-kenteli, \&c. the valley of the Surhan river which, as well as the Guzar and the Shir-abad, rises in the snow-covered ridge MeshaiKentely, and receives many affluents. Some time before its annexation to Bokhara, this valley was a centre of the political life of the country, and, going back in its history, we come to a time when-a local tradition says-the population was so dense that a cat could travel upon the roofs of the dwellings from Denau to the Amu. Now the population is concentrated in the upper, better. watered parts of the valley, where we find the towns Kara-tag, Sary-djui, Yourchi, and Denau. Further east we have the valley of the Kafirnagan (the Ramid of Ibis-Dast), the source of which is about Paldorak, this river being second in size to the Surhan. An enlargement in the upper parts of its valley, running east and west, is well peopled, and contains the towns Hissar, Fyzabad, Kafirnagan, and Doshambe. Then, below Hissar, the river enters a deep ravine, Pavi-Duldul (the foot of the Duldul, the mythic horse of Ali), at the issue of which is the town Kahadian ( 460 feet high), close to the Amu-daria.

Further east, beyond the second main ridge alluded to above (its local names are-By-katyn, Mazi-melek, Avantau, \&c.), we have the basins of the Upper Oxus, i.e., of the Vaksh (or Surhab) and the Pandsh, which both, M. Maïeff observes, must be considered as the sources of the Oxus. The former rises in the glaciers of the Alai-ridge and runs, under the name of Kyzyl-soo, on the Pamir table-land. After having received a great affluent, the Muk-soo, the river bears the name of Surhab and enters the Bokhara dominions through an impracticable deep ravine, at the well-known bridge Pooli-sengui. After a short course among mountains it soon emerges on a piain some 500 feet high. Divided into many branches, the main one about 180 yards broad, it runs to its junction with the Pandj near Kurgan-tube. Only one of the affluents of the Pandj, the Kchi-Surhab (little Surhab), was explored by M. Maïeff; it is formed by two rivers, the Baldshoan and Kolab, the valley of the latter being well peopled and cultivated, notwithstanding the extensive marshes which have given their name to the town, $\mathrm{Kol}$ ab.

The population of the country consists of Usbecks and Tadjicks, the former occupying mostly the lower and better parts of the valleys, having driven the Tadjicks back to the upper parts. The banks of the Amu-daria, and especially the western parts of the country, are mostly peopled with. Kungrad-Usbecks, the Tadjicks appearing more numerous to the east. The towns contain, as usual, a very mixed population. The lower parts of the Vaksh and the Kolab valley are mostly peopled by Usbecks of the Katagan tribe. Some Kirgises have begun to found settlements in the lower parts of the Vaksh and Pandsh valleys; and some miserable Turkomans are strewn among the Usbecks on the shores of the Amu. Jews, Hindoos, and Afghans form a very small percentage of the population.

As to the climate of the country, it is easy to perceive that it must be comparatively mild. In the higher parts of the Kafirnagan valley there are occasionally falls of snow about two feet deep, but the lower parts of the valleys have a mild, rainy winter. Figs grow at Shirabad unsheltered during the winter. All kinds of corn and fruits common to Central Asia are produced in abundance. Cotton, however, is cultivated only in Shirabad, owing to facility of export to Karshi (on the Shehrsebz). Rock-salt is worked in the neighbourhoods of Guzar and on the Upper Vaksh, but it must be found also elsewhere, the salt springs being numerous. Two gold mines are known on the shores of the Vaksh, and richer ones are reported to exist in the Darvaz.

The country is under the dominion of the Emir of Bokhara, being administered by nine becks, vassals to the emir, seven in the Hissar district, and two in that of Kolab, 